\title{
AIR QUALITY MEASUREMENTS IN LAYING HENS HOUSING
}

\author{
Mirko Prodanov ${ }^{1}$, Miroslav Radeski $^{2}$, Vlatko Ilieski ${ }^{3}$ \\ ${ }^{1}$ Food Institute, Faculty of Veterinary Medicine Skopje \\ University "Ss. Cyril and Methodius" in Skopje \\ ${ }^{2}$ Veterinary Institute, Faculty of Veterinary Medicine Skopje, \\ University "Ss. Cyril and Methodius" in Skopje \\ ${ }^{3}$ Institute for Reproduction and Biomedicine, Faculty of Veterinary Medicine \\ Skopje, University "Ss. Cyril and Methodius" in Skopje
}

Received 30 June 2015; Received in revised form 30 November 2015; Accepted 15 December 2015

\begin{abstract}
Ensuring good environmental conditions of the poultry houses can be costly for the farmers, but without it losses due to poor bird health and performance due to poor air quality can be much more detrimental to net returns. The goal of this study was to investigate the variations in air quality in various areas inside the laying hen houses. Ten houses with laying hen conventional battery cages were measured for $\mathrm{O}_{2}, \mathrm{H}_{2} \mathrm{~S}, \mathrm{CO}, \mathrm{NH}_{3}$ temperature, relative humidity, $\mathrm{CO}_{2}$, airflow and luminance. The results of the physical measures showed that temperatures in the houses were between $15.31-25.6^{\circ} \mathrm{C}$, the relative humidity 48.03-81.12\%, while the luminance rarely exceeded 8 lux. As for the gasses, the values for $\mathrm{NH}_{3}$ rarely exceeded $8 \mathrm{ppm}$, although at some measuring points it reached $26 \mathrm{ppm}$. $\mathrm{O}_{2}$ was generally at $20.9 \%$, and the levels of $\mathrm{CO}_{2}$ were very low. No presence of $\mathrm{H}_{2} \mathrm{~S}$ and $\mathrm{CO}$ was detected. In this study it was concluded that the measurement of the air quality in a house can vary depending of the places this measures are taken. Multiple measurement points are important because they may make the staff aware of the problems connected to low ventilation and culmination of harmful gases. The air quality in different positions in the houses is of great importance not only for the animal welfare, but also for the safety of the staff.
\end{abstract}

Key words: laying hens, ammonia, temperature, air quality

\section{INTRODUCTION}

In intensive poultry housing systems, laying hens should be kept in good environmental conditions, ensuring good care, in order to ensure that laying hens are performing to their maximum yield capacities within their genetic potential $(1,13)$. Maintaining a proper ventilation can be costly for the farmers, but without it poor bird health and performance due to poor air quality can be much more detrimental to net returns. A part of the environmental conditions is the areal environment (8). The areal conditions in

Corresponding author: Mirko Prodanov, DVM, MSc.

E-mail address: m.prodanov@fvm.ukim.edu.mk

Present address: Food Institute, Faculty of Veterinary Medicine Skopje

University "Ss. Cyril and Methodius" in Skopje

Str. Lazar Pop- Trajkov 5-7, 1000 Skopje, R. Macedonia

Phone: ++ 38923240732

Fax:+ 38923114619

Copyright: (C) 2016 Prodanov M. This is an open-access article published under the terms of the Creative Commons Attribution License which permits unrestricted use, distribution, and reproduction in any medium, provided the original author and source are credited.

Competing Interests: The authors have declared that no competing interests exist.

Available Online First: 4 January 2016

Published on: 15 March 2016

http://dx.doi.org/10.1515/macvetrev-2016-0071 the poultry houses depend on physical (temperature, relative humidity, luminance, ventilation and dust) and chemical factors (compound of the air such as ammonia, carbon dioxide and oxygen) $(1,2)$.

In poultry houses, harmful gases like ammonia, carbon dioxide, methane, hydrogen sulfide and nitrous oxide, are generated by the hens and their waste $(1,2)$. These gases may accumulate and reach toxic levels which may cause risk to the health of both chickens and the workers, therefore an adequate ventilation must be maintained. Levels of $\mathrm{CO}_{2}$ such as $12000 \mathrm{ppm}$ were observed to have effect on weight loss in broilers (3). For the CO level of $1500 \mathrm{ppm}$ in the air can cause death in an hour $(4,5,6)$. Levels of ammonia as low as 20 ppm have been shown to increase the susceptibility of chicken to diseases (7). Although poor aerial conditions normally don't cause disease directly, they do reduce the chickens' immune defenses, therefore making them more susceptible to existing viruses and pathogens (8).

The most common air contaminant in the poultry facilities is ammonia. The concentration 
varies depending on many factors, among which are manure handling, temperature, humidity and ventilation rate of the facility. Hens exposed to high levels of ammonia can show reduction in feed consumption, feed efficiency, weight gain, and egg production (8-12).

In the process of regulating temperature, relative humidity and gases, ventilation is of great importance. In laying hen houses the recommended optimal temperature is $18^{\circ} \mathrm{C}(13)$. The measures of performance such as body weight, consumption of feed and water, feed intake, egg production, and egg weight, have been correlated with the environmental temperature (14). It is possible that under heat stress, a reduction of egg production occurs due to the alterations in the respiratory pattern (15).

It is advised that the optimal relative humidity in laying hen houses should be between 50-70\% (16). If the relative humidity drops below the advised levels increases of mortality, and in some cases respiratory diseases can accrue (16).

The goal of this study was to investigate the variations of air quality, except dust levels, in various areas inside the laying hen houses.

\section{MATERIAL AND METHODS}

Ten houses with laying hen conventional battery cages were measured for the air quality. Seven of the houses were completely closed with no windows and had tunnel ventilation type. Two of the houses $(G 1, G 2)$ had windows which were open in order to increase the ventilation and a fan at each corner that was sucking air out of the house, and one house (D) had fans pumping air out of the house on one side and openings on the other side where fresh air was entering the house. Detailed information about the houses are given in Table 1.

All the measurements were taken in October and November in the period between 9 a.m. and 12 a.m. when the eggs were collected. The measuring was performed inside the houses at 9 points at multiple cage heights. The points of measurements were: 3 at the corridor next to the left wall, 3 at the corridor in the middle of the batteries, and 3 points at the corridor next to the right wall. At each corridor, measurements were taken at the beginning, at the middle and at the end of the battery. The measurements of $\mathrm{O}_{2}, \mathrm{CO}$ and $\mathrm{NH}_{3}$ were done with a portable detector MultiRAE (RAE systems, US) and temperature, relative humidity, $\mathrm{CO}_{2}$, airflow and luminance was measured with TESTO measurement instrument (Testo Inc., US) with multiple sensor probes. For every house, an average value and the standard variation were calculated for each measure.

\section{RESULTS}

Summary of the results from the measurement of the physical parameters are shown in Table 2. The temperature in the houses was in the range between $15.31^{\circ} \mathrm{C}$ and $25.6^{\circ} \mathrm{C}$ with the highest standard deviation of $3.09^{\circ} \mathrm{C}$. The deviation in temperature in a house depended on the heights of the battery and the air flow. The relative humidity was between $48.03 \%$ and $81.12 \%$ with the maximum standard deviation of $4.89 \%$. The luminance was between 1.83 and 28.25 lux with maximal standard deviation

Table 1. Information about the houses where the study air quality measurements were performed

\begin{tabular}{lcccccc}
\hline House & Hybride & $\begin{array}{c}\text { Age } \\
\text { (weeks) }\end{array}$ & Population & $\begin{array}{c}\text { House size in meters } \\
\text { (W } \mathbf{~} \text { x H) }\end{array}$ & $\begin{array}{c}\text { Ventilation } \\
\text { method }\end{array}$ & $\begin{array}{c}\text { Manure } \\
\text { menagement }\end{array}$ \\
\hline House A & Dekalb brown & 69 & 35600 & $10 \times 70 \times 4,20$ & Tunel & Belt \\
\hline House B1 & Lohmann white & 30 & 13000 & $9 \times 72 \times 3,6$ & Tunel & Belt \\
\hline House B2 & Lohmann white & 88 & 15000 & $9 \times 72 \times 3,6$ & Tunel & Belt \\
\hline House C1 & ISA Brown & 48 & 11000 & $12,5 \times 80 \times 4,6$ & Side vents & Scraper \\
\hline House C2 & ISA Brown & 30 & 11000 & $12,5 \times 80 \times 4,6$ & Tunel & Scraper \\
\hline House D & Lohmann white & 72 & 9800 & $8 \times 50 \times 4,20$ & Tunel & Belt \\
\hline House F1 & Lohmann white & 53 & 54600 & $23 \times 72 \times 6,5$ & Tunel & Belt \\
\hline House F2 & Lohmann white & 40 & 59300 & $23 \times 72 \times 6,5$ & Tunel & Belt \\
\hline House G1 & Lohmann white & 52 & 22100 & $12 \times 83,5 \times 2,4$ & Modification & Scraper \\
\hline House G2 & Lohmann white & 84 & 22100 & $12 \times 83,5 \times 2,4$ & Modification & Scraper \\
\hline
\end{tabular}




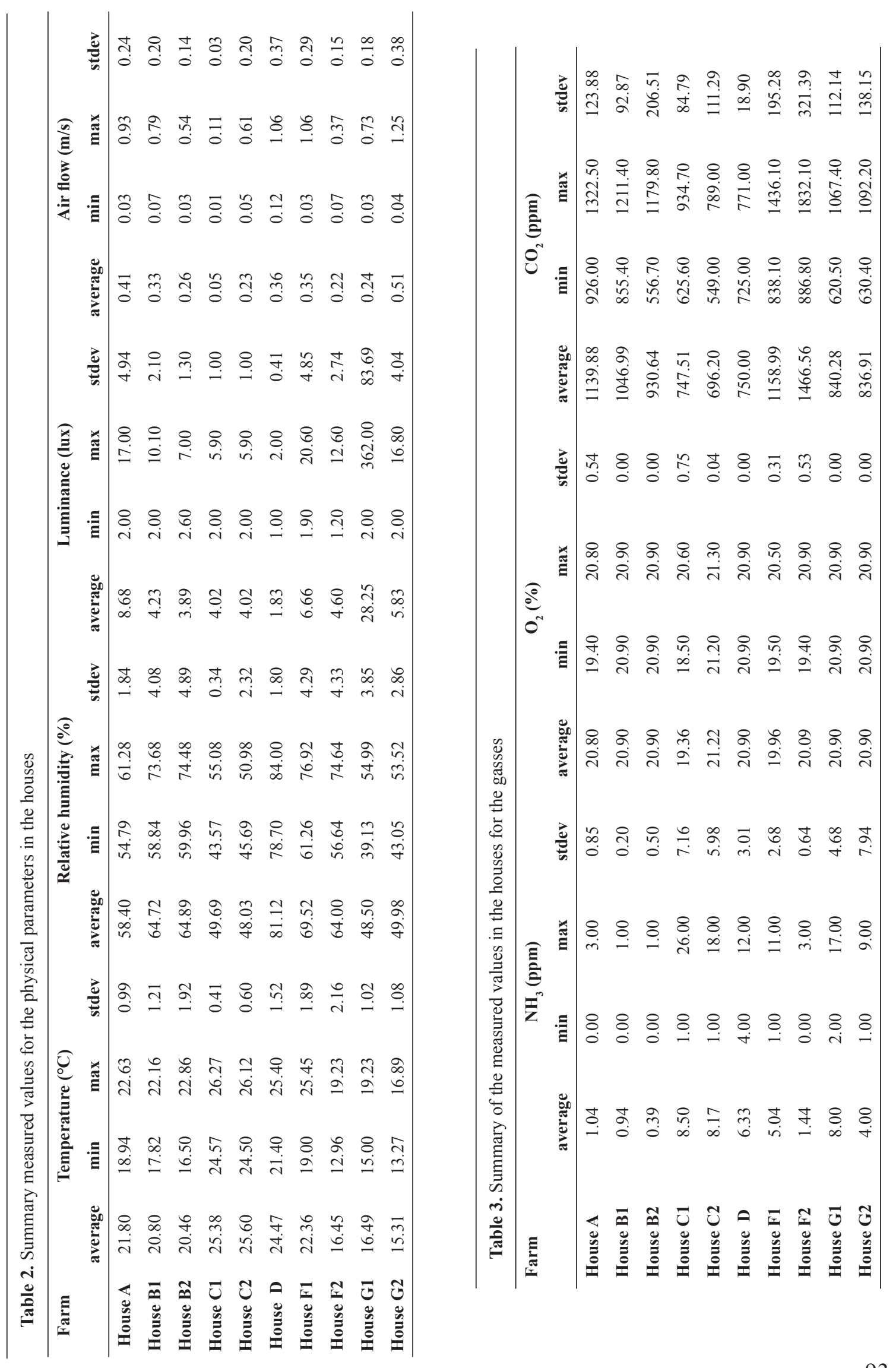


83.69 lux. Different cages were getting different amounts of luminance. The ones that were the closest to the light source had higher value for luminance, as the lower cages got the lower value for luminance. In one of the houses one of the sides was allmost open, at this point values of 362 lux was measured. The airflow was between $0.05 \mathrm{~m} / \mathrm{s}$ and $0.51 \mathrm{~m} / \mathrm{s}$ with maximal standard deviation of $0.38 \mathrm{~m} / \mathrm{s}$.

Summary of the results from the measurement of the gases are shown in Table 3. The $\mathrm{NH}_{3}$ was between $0.39 \mathrm{ppm}$ and $8.17 \mathrm{ppm}$ with the biggest standard deviation of $7.94 \mathrm{ppm}$. The $\mathrm{O}_{2}$ was between $19.36 \%$ and $21.22 \%$ with the biggest standard deviation of $0.75 \%$. The $\mathrm{CO}_{2}$ was between $696.2 \mathrm{ppm}$ and $1466.56 \mathrm{ppm}$ with the biggest standard deviation $321.39 \mathrm{ppm}$. In all the farms, it was noted that there were blind spots of ventilation. In one of the houses there was a point where the air flow was at minimum as low as $0.01 \mathrm{~m} / \mathrm{s}$, and at this point the highest concentration of $\mathrm{NH}_{3}(26 \mathrm{ppm})$ was measured. Also the amount of oxygen in most of the farms was at the level of $20.9 \%$, which is same as fresh air. However in one of the farms an alarmingly low level (18.5\%) of $\mathrm{O}_{2}$ was measured. This was the same farm that had the lowest ventilation rate. $\mathrm{CO}$ and $\mathrm{H}_{2} \mathrm{~S}$ were not detected in any of the houses.

\section{DISCUSSION}

The average temperature in the farms did not vary more than $3^{\circ} \mathrm{C}$ below, and $8^{\circ} \mathrm{C}$ above the recommended values. The highest value measured was $26.27^{\circ} \mathrm{C}$. Oarad et al. (17) stated that temperatures above $27^{\circ} \mathrm{C}$ can reduce the productive performance of the hens, and temperatures over $35^{\circ} \mathrm{C}$ can lead to pronounced decrease of feed consumption and egg shell thickness. According to Talukder (18) feed consumption and egg weight gradually decrease with relative humidity above $70 \%$, which was the case only in one of the houses. Although the mean value exceeded $70 \%$ in 4 other houses the maximum values exceeded this relative humidity. As for the luminance it generally had low values which are reported to reduce the risk of pecking (19). However the variation between the values was dependent on the distance of the measuring point from the light source. In one of the houses, at one of the sides, the panel for the opening fell off and thus did not block any light, and the values were close to those of daylight. The highest level $\mathrm{CO}_{2}$ measured in any of the houses was $1436 \mathrm{ppm}$ and it was never close to concentrations that can be harmful for the health (3). The average levels of $\mathrm{NH}_{3}$ in the houses did not exceeded $8 \mathrm{ppm}$. 94
However in one of the houses, at one measuring point, the $\mathrm{NH}_{3}$ level reached $26 \mathrm{ppm}$, a concentration which has been recorded to have adverse effects on the health of the birds and the workers $(9,20,21,22)$.

During the measurements of the houses with the tunnel ventilation a pattern was noticed. The maximum values for temperature, relative humidity and the minimal values of airflow were recorded at the measurement points located at the back end of the houses, especially at the corners. At these measurement points the maximal values for the $\mathrm{NH}_{3}$ were recorded, which is according to the literature where the levels of the $\mathrm{NH}_{3}$ is dependent of temperature, relative humidity and airflow (23).

\section{CONCLUSION}

In this study it was concluded that the air quality in a house can differ depending of the places this measurements are taken. Multiple measurement points are important because they may make the staff aware of the problems connected to low ventilation and culmination of harmful gases. The air quality in different positions in the houses is of great importance not only to the animal welfare, but also to the safety of the staff. Although there was no repeated detection of gasses at levels that can be harmful in this study, it does give an insight to the places in the house where they are most likely to accrue.

\section{REFERENCES}

1. Kocaman, B., Yaganoglu, A.V., Yanar, M. (2005). Combination of fan ventilation system and spraying of oil-water mixture on the levels of dust and gases in caged layer facilities in Eastern Turkey. J Appl Anim Res. 27, 109-111.

http://dx.doi.org/10.1080/09712119.2005.9706551

2. Liang, Y., Xin, H., Li, H., Wheeler, E.F., Zajaczkowski, J.L., Topper, P.A., Gates, R.S., Casey, K.D., Behrends, B.B., Burnham, D.J., Zajaczkowski, F.J. (2005). Ammonia emissions from U.S. laying hen houses in Iowa and Pennsylvania. Transactions of the ASAE. 48 (5): 1927-1941. http://dx.doi.org/10.13031/2013.20002

3. Reece, F.N., Lott, B.D. (1980). Effect of carbon dioxide on broiler chicken performance. Poult Sci. 59 (11): 2400-2402.

http://dx.doi.org/10.3382/ps.0592400 PMid:6780990

4. Stiles, G.W. (1936). Carbon monoxide poisoning in chickens. Poult Sci. 15(3): 270-272.

http://dx.doi.org/10.3382/ps.0150270 
Air quality measurements in laying hens housing

5. Breurec, J.Y., Valancony, V., Blevin, F., Baert, A., Charles, D., Arzel, Y., Presle, J.C., Curtes J.P. (1999). Carbon monoxide poisoning among poultry breeders. Indoor and Built Environment 8 (3): 193-198. http://dx.doi.org/10.1177/1420326X9900800312

6. Carlson, H.C., Clandinin, D. R. (1963). Carbon monoxide poisoning in chicks. Poultry Sci. 42 (1): 206-214.

http://dx.doi.org/10.3382/ps.0420206

7. Anderson, D.P., Beard, C.W., Hanson, R.P. (1964). The adverse effects of ammonia on chickens including resistance to infection with New castle disease virus. Avian Dis. 8 (3): 369-379. http://dx.doi.org/10.2307/1587967

8. Quarles, C.L., Kling, H.F. (1974). Evaluation of ammonia and infectious bronchitis vaccination stress on broiler performance and carcass quality. Poul Sci. 53, 1592-1596. http://dx.doi.org/10.3382/ps.0531592

9. Charles, D.R., Payne, C.G. (1966). The influence of graded levels of atmospheric ammonia on chickens. Brit Poul Sci. 7 (3): 189-198. http://dx.doi.org/10.1080/00071668608415623 PMid:6007527

10. Wang, Y.M., Meng, Q.P., Guo, Y.M., Wang, Y.Z., Wang, Z., Yao Z.L., Shan T.Z. (2010). Effect of atmospheric ammonia on growth performance and immunological response of broiler chickens. J Anim Vet Adv. 22 (9): 2802-2806. http://dx.doi.org/10.3923/javaa.2010.2802.2806

11. Deaton, J.W., Reece, F.N., Lott, B.D. (1984). Effect of atmospheric ammonia on pullets at point of lay. Poult. Sci. 63 (2): 384-385.

http://dx.doi.org/10.3382/ps.0630384

PMid:6709574

12. Deaton, J.W., Reece, F.N., Lott, B.D. (1982). Effect of atmospheric ammonia on laying hens performance. Poult. Sci., 61 (9): 1815-1817. http://dx.doi.org/10.3382/ps.0611815 PMid:7134135

13. Thiele, H. H., Pottgüter, R. (2008). Management recommendations for laying hens in deep litter, perchery and free range systems. Lohmman Information 43, 53-63.

14. Sterling, K.G., Bell, D.D., Pesti, G.M., Aggrey, S.E. (2003). Relationships among strain, performance, and environmental temperature in commercial laying hens. J App Poult Res. 12, 85-91.

http://dx.doi.org/10.1093/japr/12.1.85
15. Xin, H., De Shazer, J.A., Beck, M. M. (1987). Posteffect of ammonia on energetics of laying hens at high temperatures. Transactions of the ASAE. 30 (4): 1121-1125.

http://dx.doi.org/10.13031/2013.30530

16. Czarick, M., Farichild, B. (2012). Relative humidity... The best measure of overall poultry house air quality. Poultry Housing Tips [Internet] [cited 2015 November 5]; 24 (2). Available from: https://www.poultryventilation.com/tips/vol24/n2

17. Oarad, Z., Marder, J., Soller, M. (1981). Effect of gradual acclimatization to temperature up to $44^{\circ} \mathrm{C}$ on productive performance of the desert Bedouin fowl, the commercial white Leghorn and the two crossbreds. Br Poult Sci. 22, 511-520. http://dx.doi.org/10.1080/00071688108447918

18. Talukder, S., Islam, T., Sarker S., Islam, M.M. (2010). Effects of environment on layer performance. J Bangladesh Agril Univ. 8 (2): 253-258.

19. Appleby, M.C., Hughes, B.O., Elson, H.A. (1992). Poultry production systems: Behaviour, management and welfare. CAB International, Wallingford, United Kingdom.

20. Carlile, F.S. (1984). Ammonia in poultry houses: a literature review. World's Poult Sci J. 40 (2): 99-113. http://dx.doi.org/10.1079/WPS19840008

21. Ning, X. (2008). Feeding, defecation and gaseous emission dynamics of W-36 laying hens. Graduate Theses and Dissertations. Paper 11575. Iowa State University. [cited 2015 May 18] http://lib.dr.iastate.edu/etd/11575

22. Reece, F.N., Lott, B.D. (1983). The effects of temperature and the age on body weight and feed efficiency of broiler chickens. Poult Sci. 62 (9): 19061914.

http://dx.doi.org/10.3382/ps.0621906

PMid:6634619

23. Li, H. (2006). Ammonia emissions from manure belt laying hen houses and manure storage. Retrospective Theses and Dissertations. Paper 1273 Iowa State University. http://lib.dr.iastate.edu/rtd/1273 